\title{
INFLUENCE OF DIFFERENT DIETS ON HONEYBEE WORKERS (APIS MELLIFERA L.) HAEMOCYTES
}

\author{
DIAB, A.M. ${ }^{1}$; I.A.A. SHEHATA ${ }^{1}$; \\ E.A. NAFEA ${ }^{2}$ and M.L. ABDALLAH ${ }^{2}$
}

1. Faculty of Agriculture . Al-Azhar Univ.

2. Plant Protection Research Institute, Agriculture Research Centre.

(Manuscript received 11 July 2018)

\begin{abstract}
$\mathrm{T}$ he influence of different diets on the haemolymph of adult honey bee worker was examined. Four diets were compared for measuring their effect on the different haemocytes types and count of the newly emerged workers bees'. Four groups of newly emerged worker bees were fed with one of the following diets in patty form with pollen and pollen substitute, soya bean, cheak pea, yeast. Differential haemocytes counts were evaluated. The types of the haemocytes (plasmocytes -coagulocyte. granulocyte) were recorded, the most abundant types was plasmocytes cells over $42 \%$ followed by coagulocyte $33 \%$ and granulocytes $24 \%$. The highest total haemocytes count was 1345 cell for pollen, while the lowest total was 931.66 cells for pollen substitute, the examined pollen substitute caused decreased of total haemocytes count.
\end{abstract}

\section{INTRODUCTION}

Haemocytes are fundamental importance in the preservation of an insect haemocytes especially in regards of cellular defense reaction and management of nitration elements Glinski and Jarosz, (1995). These cells circulating in haemolymph are easily accessible to evaluate an insect haemocytes and analysis of haemocytes enable the estimation of the influence of different factors external factors such analysis should be particularly useful to assess diet and therapeutic treatment for honey bee as well as chemicals for plant protection recommend as not harmful to bees examination of haemocytes many also be useful to determined the effect of environmental factors on range of immune parameters of cellular system of honey bee haemolymph .Total haemocytes counts (THC), differential haemocytes count. And metabolic activity. Metabolic activity was used as an indirect estimation of ability of cells to phagocytosis Glinski and Klimont (1987). Insect's haemolymph plays very important role in transport and storage of nutrients and is crucial for the recognition and defense against micro-organism (Bogart et al, 2009). Honey bees possess an open circulatory system and mummeries haemocytes are contained in its haemolymph. Plasmocytes, graniular cells, cystocites, sphaerula, and oenocytes are the cells that comprise the bee haemocytes population (Gupta, 1991). Thy are variable in morphology and functions. They are responsible for the defense fraction 
pathogens pernterate haemocole (Tepass et al., 1999): Fallers and Gregrio, 1995; Glinsk and Jaroza, 1995, and Inoue, et al., 2001), perform phagocytes encapsulation of foreign bodies in the insect body cavity, coagulation to prevent loss of body, module formation, transport of food matered (Patton, 1983). The haemocytes can imgulaf and destroy small foreign objects such as bacteria, fungal, but larger parasites, bacteria or fungal hypha are encapsulated by several haemocytes and then removed from circulation (Glinskiand Jaroz, 2001).The aim of this experiment was to estimate the influence of different feeding diets (pollen and pollen substitute) on the differential haemocytes count in newly emerged honey bee worker.

\section{MATERIALS AND METHODS}

This study was carried out in the year 2016 and the observations were made in early summer. The experimental groups of bees (Apis mellifera L.) were fed bee pollen with sugar candy (natural proteinaceous food) and pollen substitute was multi component food. This pollen substitute was made of following raw materials; soya powder (A), cheak pea (B) and Yeast (C). The pollen substitute was mixed with powdered sugar, distilled water was added to obtain patty .The diet cakes were placed dried over the center of the brood combs and the top of the cake was covered with wax paper to prevent moisture loss. The experimental colonies were subjected to this different treatment, weekly from early summer 2016 and continued for one year. Investigated bees were collecting by placing frames with emerge brood from each colony fed with these feeding treatment in incubator set to $33^{\circ} \mathrm{C}$ and the relative humidity of $65 \%$ till the worker honey bee emerge .A drop of the haemolymph of the newly emerged worker was taken over a clean microscope slide and smear was made "Smears were stained with Giemsa stain and different haemocytes count (DHC) were evaluated .One hundred cells were counted per slide and oil immersion and phase contrast using light leitz microscope. The types of the haemocytes plasmatocytes, granulocytes and coagulocyte were recorder using the key of Gupta (1991) .About 30 smears of haemolymph for each diet were examined.

\section{RESULTS AND DISCUSSION}

Haemocytes play on essential role in defending insects against invading parasites and pathogens and is the effective physiological meekness of phagocytes encapsulation, and other related defense mechanism were primarily duty to availability of circulation immune cells particularly plasmatocytes and granulocyte. Feeding honey bee with different diets may help enhancing the enmity of bees to their positive effect on the types and percentage at haemocytes

Three haemocytes types were observed in the haemolymph of the newly emerged honey bee worker were fed on different kind of diet are presented in 
fig (1) table (1) and (2). They were classified as plasmocytes, coagulocyte and granulocytes or other Shimanuki (1971), following Jedruszik (1997). Plasmocytes were smal round cells with compact, round nuclei and thin hyaline meutrophilic. Granular haemocytes were large, oval or ellipsoidal cells with granular nucleic and vacuolated cytoplasm .Coagulocyte are spherical or oval cells, the nucleus is relativity small, rounded or elongate and is centrally located. The predominant type of the haemocytes of bees fed with the four test diet was the plasmatocytes cells followed by the coagulocyte and granulocytes. Our results are in agreement with those of previous studies which mentioned that the plasmocytes were the most numerous cells in the haemolymph of young honey bee from -free flying colonies Jedruszuk, (1998) .a.b and c

The results also confirm observation made earlier by Wieland's et al., (1987) examination of plasmocytes only may not be sensitive enough, as the next consequence of different diet but also they were a large decrease in proportion of metabolically active cells, which suggests a reduced ability to phagocytes .The plasmocytes recorded the highest occurrence in bee fed different diets $41.2 \%$ while the low percentage was found for both (Co) and (Gr) 32\%, 24\%, white they revealed respectively. There were significant differences between the effect of different pollen and pollen substitute on honey bee haemocytes. Data in table (2) clear that the total haemocytes count of the worker adult fed different diets was 1345 cells per $\mathrm{mm}^{3}$, the lowest for pollen grain, while total haemocytes count worker adult was 931.66 cells $\mathrm{mm}^{3}$ for pollen substitute. There was significant difference between the pollen and the all other different diets. From the previous results it was noticed that the plasmocytes are the most abundant cells followed by (Co) and (Gr). These results agreed with those of Szymas and Jedruszuk (2003), who mentioned that there was significant higher percent type plasmocytes and a significant decrease of ( $\mathrm{Gr}$ ) in the haemolymph of bees fed with pollen substitute, compared with the haemocytes systems of bees fed with pollen. Phagocytosis and encapsulation are two common types of defense reaction in honey bee against invading pathogenesis. Encapsulation began where granular cells attached to the foreign target and this was followed by attachment of multiple layers of plasmocytes to from the outer layer of the capsule Louis and Michaed (1996); Gliinski and Jaroza (2001) and Glinski and Buczek, (2003).

The physiological mechanism effect of phagocytosis encapsulation and other related defense mechanisms was due to the availability of circulatory in nuchal cells particularly plasmocytes and granulocytes Sanjayan et al., (1996). Bee haemocytes may directly kill bacteria, fungal spoors and other small foraging molecules phagocytes process Gotz (1986). 
Researchers found a correlation between diet diversity (poly Loral pollen pollen substitute) and healthy immune system in honey bees in laboratory experiment, and that bees fed on different types of pollen had higher levels of glucoses oxidase than bees that were fed only on type of pollen even if that on type had higher protein content bees Trinde (1969). As mentioned earlier glucose as oxidase is used by the bees to preserve honey and protect the hive against pathogens (Alaux et al., 2010) the effect of different diets were assessed by measuring haemocytes concentration and haemocytes are necessary for phagocytosis and encapsulation of parasite and fat bodies provide antimicrobial peptide synthesis. (Alaux et al., 2010), while haemocytes activity did not seen to be affected by the pollen source, both bat body and glucose oxidase activity were significantly enhanced. The authors concluded that varied diet yielded more of amino acids necessary to increase antiseptic protection of the hive (Alaux et al., 2010)

Table 1. percentage of different haemocytes content of worker honey bee feeding with different diets .

\begin{tabular}{|c|c|c|c|c|c|c|c|c|}
\hline \multirow{2}{*}{ group } & \multirow{2}{*}{$\begin{array}{c}\text { Pollen } \\
\text { (control) }\end{array}$} & \multirow[b]{2}{*}{$\%$} & \multicolumn{6}{|c|}{ Diet with Pollen substitute } \\
\hline & & & Soya bean & $\%$ & Cheak pea & $\%$ & yeast & $\%$ \\
\hline Total haemocytes & 1345 & & 1186.66 & & 1055.66 & & 931.66 & \\
\hline plasmocytes & & 42.52 & & 41.71 & & 41.77 & & 40.71 \\
\hline coagulates & & 32.88 & & 33.13 & & 33.08 & & 33.08 \\
\hline granulocytes & & 24.52 & & 25.14 & & 24.9 & & 26.19 \\
\hline
\end{tabular}

Table 2. Influence of feeding bee colonies with different diets on haemocytes number cell per $\mathrm{mm}^{3}$ ( $\mathrm{R}=$ replicate)

\begin{tabular}{|c|c|c|c|c|c|c|c|}
\hline Different diets & R1 & R2 & R3 & Mean & F & P & LSD0.05 \\
\hline Soybean & 1225 & 1165 & 1170 & 1186.66 & & & \\
Cheek bean & 108.3 & 1056 & 1020 & 1055 & \multirow{2}{*}{130.60} & \multirow{2}{*}{0.000} & 50.59 \\
\cline { 1 - 5 } Yeast & 957 & 930 & 608 & 931.66 & & & \\
\hline pollen & 1362 & 1346 & 1327 & 1345 & & & \\
\hline
\end{tabular}

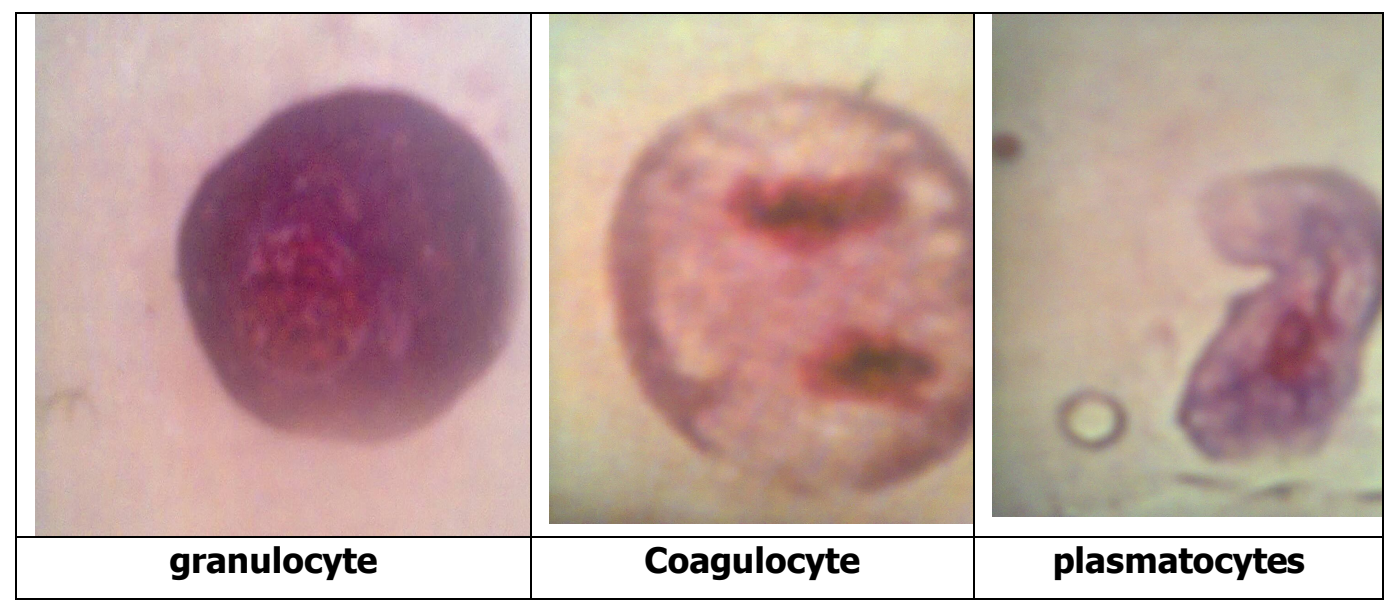

Fig. 1. Kinds of honey bee worker haemocytes 


\section{REFERENCES}

1. Alaux,C.; F. Ducloz; D. Crauser and Y. lecomte. 2010. Diet effects on honey bee immune -competence. Biology .letters.

2. Bogart, A.; G. Baggerman; E. Vierstraete; L. Schools and P. Verlaine. 2009. The hemolymph protein of the honey bee: Gel-based or gel-free? Proteomic , 9:32013208.

3. Falleres, A.; M .F. and E.A. Greggorio. 1995. Hemoocito fugochtarios em lervas. Diarrhea saccheralis (fabrics) (Lepidoptera). Evista Brasileira de Zoologia , 12(4):751-758

4. Glinski, Z. and S. Klimont. (1987a). wplyw inwazji Varroa jacobsoni oud .na element komorkowe hemolimfy pszczol robot nine Apis mellifera L .,Medycyna wet .43,546-549.

5. Glinski, Z. and S. Klimont. (1987b). Aktywnosc hernocytow pszczol robotnio w przebiegu naturalnego zarazenie Varroa Jacobsoni oud ., .Medycyna wet .43,664-667 .

6. Gupta, A.P. 1991. Immunology of Insects and other Arthropods. CRC press, Boca Raton. FL.

7. Glinski, Z. and J. Jarosaz. 1995. Mechanical and biochemical defenses of honey bees, Bee world 76,110-118 .

8. Glinski, Z. and k. Gizegorozyk. 1995. Cellular defense Reaction in the honey bee in environment non-polluted with heavy metals, Ann. Univ. Marie curie sktodowsks /dd 50.131-137.

9. Glinski, Z. and J. Jarosaz. 2001. Infection and immunity in the honey bee, Apis mellifera L Apiacta ,36(1):12-24

10. Glinski Z. and K. Buczek. 2003. Response of the Aoidea to fungal infection Apiacta,38: 183-189.

11. Gotz, P. 1986. Encapsulation in Arthropods. In Breehelin, M:Boemaee N. (eds)immunity in Invertebrates. Springer Verlage, Berlin, Heidelberger, pp .153170.

12. Inoue, N.; K.T. Hanada; I. Igarashi; H.M.T. Nagasawa and K. Eujisaki. 2001. Characterization of phagocytic in Ornithodros Moabite (Acari:Ixodidae). Medical Entomol, 35(5):514-519.

13. Jedruszuk, A. (1998a). Age-dependence of metabolic activity of haemocytes in haemolymph of adult worker honey bees from spring -summer generation, pszczol .Zesz. nark. XLII2,41 -42. 
14. Jedruszuk, A. (1998b). Total haemocytes counts in haemolymph of adult worker honey bees (Apis mellifera L) from spring -summer and autumn winter generation, pszczol, Zesz. Nauk .XLII 2:43-44 .

15. Jedruszuk, A. (1998c). Wstepna analyze zmian obrazu hemolimfy pod wplywem wieku u pszczolrobotnic $A$.mellifera, XXXV Nauk. Konf .pszczol pulawy 11-12 maraca 1998, pp.32-33.

16. Kedruszuk, A. 1997. Uproszczoma systematyka kornorek hemolimfy pszczol mhodnej (Apis mellifera L.) materiaty XIII nankowej konferencjh warroza pszczol I gospodarka pasieczna, Olsztyn -kowtow pp. 28-30.

17. Louis, L.P. and R.S. Michael. 1996. Granular cells are required for encapsulation foreign targets by insect haemocytes .J. Cell Sci. 109:2053-2060.

18. Manning, R. 2001. Fatty acids in pollen: a review of their importance for honey bees. Bee World, 82(2):60.75.

19. Patton, R.L. 1983. Introductory insect's phycology. W.B Saunders Co. Philadelphia .47,65 pp.

20. Sanjayan, K.P.; T. Ravikumar and S. Albert. 1996. changes in the haemocytes profile of Spilostethus hopes (fab) (Heteroptera : Lygaeidae )in relation to eclosion ,sex and mating .J.Biosci., 21(6):781-788.

21. Szymas, B. and A. Jedruszuk. 2003. The influence of different diets on haemocytes of adult worker honey bess, Apis mellifera. Apidologie 34:97-102 .

22. Tepass, U.; L.L. Fessler, A. Aziz, and V. Hartenstein. 1994. Embryonic origin of haemocytes and their relationship to cell death in Drosophila Development .120:1829-1837.

23. Trinder, P. 1969. Enzematic determination of sugar in serum and plasma .Amm . Clin .Biochem.,6:27.

24. Wienands, A. and G. Madel. 1998. Hamozyten der honigbiene, Apis Mellifera und hire $\mathrm{V}$ eranderungen durch Varroatose (Hymenoptera, Apidae), Enntomol.Gen .14.81-92 .

25. Wienands, A.; H. Stric and G. Madel. 1987. Varroatosis: haemocytes and bacteriological aspects of haemolymph of Apis mellifera L (Hymenoptera, Apidae), Zentrablbl. Bakteriol., Microb. und Hyg.265,489. 


\title{
تأثير التغذية المختلفه على خلايا دم شغالات نحل العسل
}

\author{
عادل دياب محمد 1 ، ابرهيم عبدالر ازق شحاته1 1 ، عمداد \\ عماد الدين احمد عبدالحميد2 و محمود لطقى عبداب الله عبد 2 \\ 1- قسم وقايه النبات - كليه الزراعه - جامعه الازهر. \\ 2- معهد بحوث وقايه النباتات - مركز البحوث الزراعيه الزعابه -الدقى - جيزه.
}

در اسه ناثير التغذيه المختلفه على خلايا هيمولمف شغالات نحل العسل حديث الخروج 4

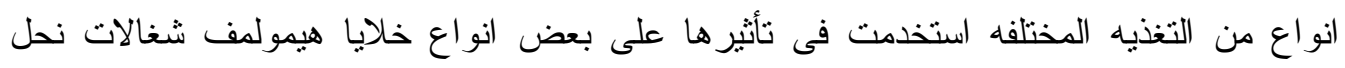
العسل وهى عباره عن ثلاث مركبات غذائيه كبديل لحبوب اللقاح و استخدمت حبوب اللقاح كمقارنه لهذه البدائل و هذه البدائل مطحون الفول الصويا - مطحون حمص حلو - وخليط من العجوه و الخميره الطبيه الجافه وقد اظهرت النتائج انه نم تعريف ثلاثه انواع من خلايا الدم

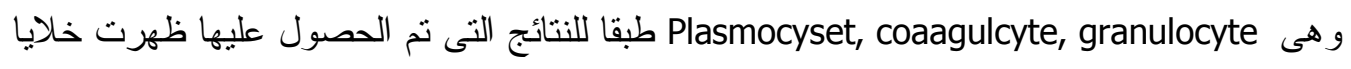
البلازموسيت باعلى نسبه فى هيمولمف الشغلات وقدرت نسبه وجودها ب42\% بينما وجود النوع

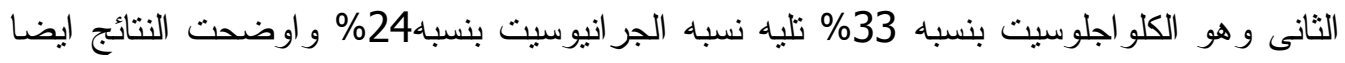
ان الطو ائف التى غذيت على حبوب القاح اعطت اكبر عدد من خلايا الدم (1345 خلايا) بينما اقل لتل قيمه سجلت على خلايا الدم فى الطو ائف النى غذيت على بدائل حبوب اللقاح (931 خليه). 
